\title{
Disaster risk reduction in the Omusati and Oshana regions of Namibia
}

\begin{tabular}{|c|c|}
\hline $\begin{array}{l}\text { Authors: } \\
\text { Elina Amadhil } \\
\text { Loide Shaamh } \\
\text { Gert van Rooy } \\
\text { Nguza Siyamb }\end{array}$ & $u_{1}^{12,3}$ \\
\hline \multicolumn{2}{|c|}{$\begin{array}{l}\text { Affiliations: } \\
{ }^{1} \text { Social Sciences Division, } \\
\text { University of Namibia, } \\
\text { Namibia }\end{array}$} \\
\hline \multicolumn{2}{|c|}{$\begin{array}{l}{ }^{2} \text { African Centre for Disaster } \\
\text { Studies, North-West } \\
\text { University, South Africa }\end{array}$} \\
\hline \multicolumn{2}{|c|}{$\begin{array}{l}{ }^{3} \text { Life Sciences Division, } \\
\text { University of Namibia, } \\
\text { Namibia }\end{array}$} \\
\hline \multicolumn{2}{|c|}{$\begin{array}{l}\text { Correspondence to: } \\
\text { Gert van Rooy }\end{array}$} \\
\hline \multicolumn{2}{|c|}{$\begin{array}{l}\text { Email: } \\
\text { gvanrooy@unam.na }\end{array}$} \\
\hline \multicolumn{2}{|c|}{$\begin{array}{l}\text { Postal address: } \\
\text { Private Bag 13301, } \\
\text { Windhoek, Namibia }\end{array}$} \\
\hline \multicolumn{2}{|c|}{$\begin{array}{l}\text { Received: } 06 \text { Nov. } 2012 \\
\text { Accepted: } 28 \text { June } 2013 \\
\text { Published: } 21 \text { Aug. } 2013\end{array}$} \\
\hline \multicolumn{2}{|c|}{$\begin{array}{l}\text { Key words: } \\
\text { Disasters; resilience; risk } \\
\text { management; Hyogo } \\
\text { Framework for Action; } \\
\text { Namibia }\end{array}$} \\
\hline \multicolumn{2}{|c|}{$\begin{array}{l}\text { How to cite this article: } \\
\text { Amadhila, E., Shaamhula, L., } \\
\text { Van Rooy, G. \& Siyambango, } \\
\text { N., 2013, 'Disaster risk } \\
\text { reduction in the Omusati and } \\
\text { Oshana regions of Namibia', } \\
\text { Jàmbá: Journal of Disaster } \\
\text { Risk Studies 5(1), Art. \#65, } \\
9 \text { pages. http://dx.doi. } \\
\text { org/10.4102/jamba.v5i1.65 }\end{array}$} \\
\hline \multicolumn{2}{|c|}{$\begin{array}{l}\text { Copyright: } \\
\text { C 2013. The Authors. } \\
\text { Licensee: AOSIS } \\
\text { OpenJournals. This work } \\
\text { is licensed under the } \\
\text { Creative Commons } \\
\text { Attribution License. }\end{array}$} \\
\hline Read online: & $\begin{array}{l}\text { Scan this QR } \\
\text { code with your } \\
\text { smart phone or } \\
\text { mobile device } \\
\text { to read online. }\end{array}$ \\
\hline
\end{tabular}

Namibia often experiences heavy rains in the north and north-eastern parts of the country, which results in severe flooding. For this reason, the country has endorsed the Hyogo Framework for Action (HFA) which seeks to develop the resilience of nations and communities to disasters and to assist countries to move away from the approach of emergency response to one of integrated disaster risk reduction. The aim of this article is to assess the resilience of the communities within the identified regions. A quantitative questionnaire was designed to assess people at risk of disaster related impacts. The questionnaire used 20 indicators to measure the level of progress at local level and how local governance plays a role in the mitigation and management of disasters. Analysis of data was done on a limited number of descriptors such as age, gender and local governance involvement, amongst others. There was generally a very high perception of threat (38\%) in the study regions. Women perceived threat more accurately (mean $=4.09)$ than men. The community perceived threat more accurately than local government and civil society (mean $=4.08)$.

\section{Introduction}

Disasters, however 'natural', are profoundly discriminatory. Wherever they hit, pre-existing structures and social conditions determine that some members of the community will be less affected while others will pay a higher price. (Maguire \& Hagan 2007:17)

Natural hazards such as floods, droughts and storms affect millions of people in Africa every year, frequently with devastating impacts.

Disaster risk reduction is defined as a systematic approach to identifying, assessing and reducing the risks of disaster. It aims to reduce socio-economic vulnerabilities to disaster as well as dealing with the environmental and other hazards that trigger them (Twigg 2007).

Natural hazards have long been considered a tragic disruption to the development process. This is because lives are lost, social networks are disrupted, and capital investments are destroyed. When development plans are laid and disaster strikes, government funds are diverted to the emergency. Additional aid is directed to relief and reconstruction needs to get the country 'back on track' toward economic and social development (Kreimer \& Arnold 2000).

During 2008 and 2009, Namibia experienced heavy rains in the north and north-eastern parts of Namibia, which resulted in severe flooding. The heavy rains were exacerbated by the rainfall received in the neighbouring countries of Angola and Zambia. The country experienced a number of hazards between 2004 and 2009 in the south, north and north-east. From 1982 to 2008, the country had close to 19 events of natural disasters, which affected about 884953 people. The floods caused tremendous destruction to infrastructure, homes and property, loss of agricultural production and loss of lives. Between 2000 and 2007, the country experienced at least five crippling droughts which affected between 300000 to 700000 people in all 13 regions (Kobetsu 2010). Floods have been a major problem in Namibia, affecting the majority of the population, especially those living in the North Central regions of Oshikoto, Omusati, Ohangwena and Oshana, and the North Eastern regions of Kavango and Caprivi. In addition, the floods damaged infrastructure, crops, and hampered patients' access to health care and children going to school. Drawing on both literature and fieldwork conducted in northern Namibia, this article focuses on risk management, the impact of floods, and how communities cope with them.

The government of the Republic of Namibia's Emergency and Disaster Management Directorate reported that damage to roads and bridges hindered the GRN's assessment of many affected areas as accessing those areas became difficult due to the damaged infrastructure. The Namibian government intends to implement what is known as a 'master plan'. In this plan, bridges that are currently functional to make schools accessible to school-going children during the rainy 
season and additional water systems will be added to enable the effective functioning of the water flow into drainage systems. However Pelling and Wisner (2009) point out that reducing risk is much harder and more expensive when retrofitting buildings and infrastructure that are already in place. The UN-HABITAT (cited by Pelling \& Wisner 2009) is of the opinion that a first step for tackling disaster risk reduction is to identify the risk. According to them, there are many ways this can be done. One of these is that engineering and public health professionals recognise the different aspects of risk and use different kinds of tools, but on the other hand, people at risk use a different logic to recognise and evaluate competing risks. Paton and Johnston (2001:270) argue that the community as a whole is better prepared to deal with a disaster than are individuals; however, when you attribute better preparedness to a community, individuals in that community often accept the need for preparedness as something that applies to others and not to them, and so the likelihood of them attending information sessions is reduced. The argument here is that people therefore believe that the local government must take responsibility for managing their disaster as well as their safety (Paton \& Johnson 2001:270). Notwithstanding the above, it is frequently reported that the poor do not take action to reduce their exposure to environmental risks because they concentrate on the immediate demands of survival and of avoiding the physical, social and psychological risks associated with poverty.

According to Fara (2001), one of the main problems acknowledged by disaster practitioners is a lack of coherence in disaster management advocacy, a result of the fragmentation of the disaster field. There are massive differences between what theorists write about with regards to disaster management and what practitioners do. These different spheres - academics, practitioners, relief workers and civil protection structures - have evolved separately from one another, with little exchange of knowledge between them. Ahrens and Rudolph (2006) demonstrated that only if a country's governance structure enables the implementation and enforcement of public policies conducive to its economic and social development can sustainable livelihoods be achieved and susceptibility to disasters be reduced. Thus, to deal with the various debates about disaster preparedness, a risk perception model would be the ultimate way to deal with different opinions. The main component of a risk perception model will be action-outcome expectations and self-efficacy (Paton \& Johnston 2001:274). People in most cases do make assumptions about a possible consequence without prior efficacy judgment. It goes without saying that for communities to tackle disaster risk reduction they should to be actively involved in problem solving, and that this would help them develop a greater resilience to adversity (Paton \& Johnston 2001:274).

\section{Main causes and patterns of disasters in Namibia}

Namibia is considered to be one of the most vulnerable countries when it comes to the effects of climate change in subSaharan Africa. The expected climate change impacts include a decline in water availability and rising temperatures due to higher evapo-transpiration and changing rainfall patterns.
Due to dry land, a hot and dry climate and an erratic rainfall pattern, Namibia is exposed to recurrent droughts and wildfires. Flooding also occurs along Namibia's international borders where perennial rivers lie. The northern border river systems are characterised by seasonal flooding of ephemeral drainage networks in a semi-arid environment. Major floods occurred in 1960 and in the 1970s in the Caprivi and Okavango River border zones. Sudden exceptional floods in 2008 and 2009, possibly as a result of increased climate variability, caused emergency disaster conditions for the local population and infrastructural development.

The areas that were worst affected were the North Central regions of Omusati, Ohangwena and Oshana and the Oshikoto and Okavango regions in the north-east of the country. These regions are mostly in the Cuvelai River Basin, which is shared with Angola. The Caprivi and Kavango regions in the northeast of the country were also badly affected by the flooding (Figure 1).

\section{Local management of disaster through the National Disaster Risk Management Policy}

Management of disasters in the country have mostly followed a bottom-up approach. This is an indication that the community through various community structures is involved in overall disaster reporting. Van Niekerk (2006:98) defines disaster risk management as an operational embodiment of strategies in addressing the disaster risk problems within the confinement of resource constraints. Structures are put in place in an affected region to mitigate the extent of a disaster, and these include risk assessment, disaster prevention, mitigation and disaster preparedness. The question that remains is: are we doing disaster risk management or disaster management? The President of the Republic of Namibia currently is the only person who, upon

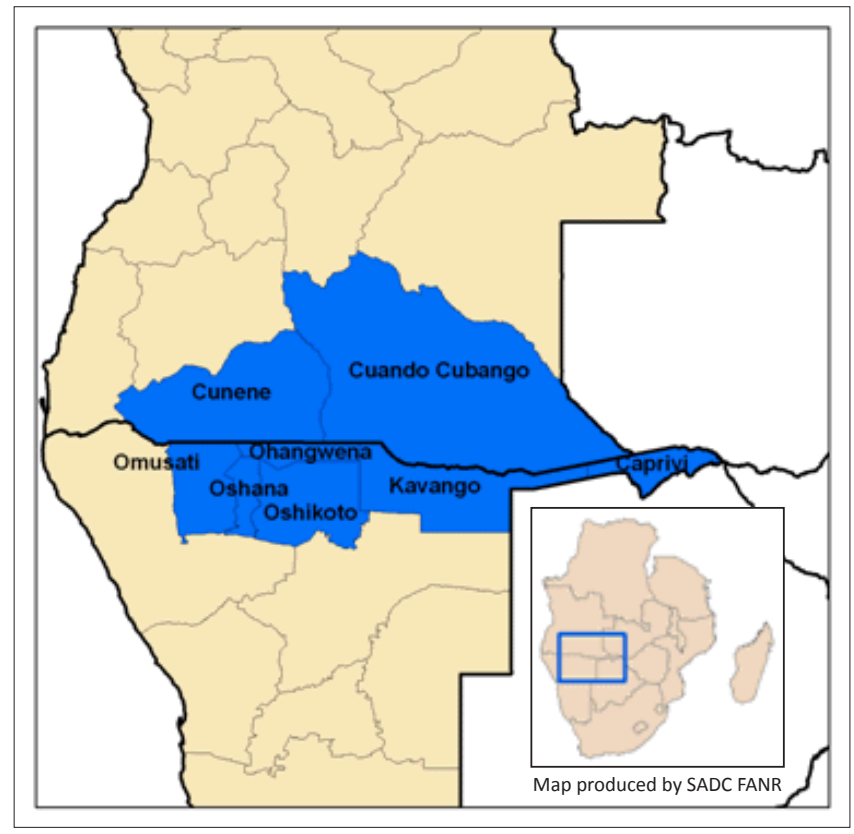

Source: Relief Web, 2009, Report on the flooding in Namibia and Angola, viewed 15 March 2011, from http://reliefweb.int/node/301823

FIGURE 1: Geographical map of flood prone areas in Namibia. 
advice, can declare a disaster as a national emergency. The aim of the National Emergency Management System is to put the nation at the highest level of preparedness for natural disasters. It tasks itself to ensure recovery from any national disaster. The system will help the country to move away from the approach of emergency response to one of integrating disaster risk reduction that is built into the developmental objectives of the country.

When a disaster occurs, the information is communicated to Cabinet through the National Disaster Risk Management Committee (NDRMC). The NDRMC is directly accountable to Cabinet through the Secretary to Cabinet. At a local level, the Settlement Disaster Risk Management Committee (SDRMC), that works closely with the community, transmits information about a possible disaster or risk to the Constituency Disaster Risk Management Committee (CDRMC). The CDRMC informs either the Local Authority Disaster Risk Management System (LADRMS) or the Regional Disaster Risk Management Committee (RDRMC), which in turn inform the Directorate Disaster Risk Management (DDRM). The DDRM, apart from line ministries, also consists of members at the local level who are part of the Vulnerability Assessment Committee (VAC). Thereafter, information reaches the NDRMC and it is then transmitted upwards to the highest authority of the country. With regard to the implementation of a disaster or risk, the National Focal Persons Forum (NFPF) and the Namibia Vulnerability Assessment Committee (NAMVAC) assist the DDRM in gathering information pertaining to the disaster or risk and oversee the effective implementation of disaster risk management at all levels. At community level, the CDRMC ensures that the community is well informed about disasters and that a disaster contingency plan and early warning system are developed. It is therefore the task of the CDRMC to work closely with communities in preparing disaster or risk assessments and to ensure that these plans, if developed, must feature in the regional disaster plans.

\section{Views from the Frontline}

The results presented in this article were primarily derived from data collected under the 'Views from the Frontline' (VFL) project. VFL, according to the Global Network for Disaster Risk Reduction, is a participatory multi-stakeholder engagement that was designed to monitor, review and report on critical aspects of 'local governance' (seen as the most important factor to build community resilience). The collecting of VFL data was based on a set of core indicators defined by the Hyogo Framework for Action (HFA).

\section{Research objectives}

Views from the Frontline is a global survey conducted every two years by the Global Network of Civil Society Organisations for Disaster Reduction (GNDR). The VFL project aims to achieve greater international and national government accountability and transparency when it comes to hearing the voices of vulnerable people. Ultimately, VFL 2011 aspires to open a political space for dialogue, building trust and understanding.
The project aims to support the effective implementation of the HFA (United Nations 2005) which Namibia has aligned itself with - a programme for improvement in disaster risk reduction - to build resilience of vulnerable people and communities at risk to disasters. Specifically, the research objectives are:

- to strengthen public accountability for effective HFA implementation by establishing independent local-level policy monitoring and reporting processes

- to strengthen collaboration between local, national, regional and international levels

- to increase dialogue and interaction between local authorities, civil society and community stakeholders to monitor progress, share information, formulate policy positions, develop partnerships and coalitions and contribute towards multi-stakeholders' efforts to implement the HFA on the ground.

The HFA is tasked to ensure recovery from any national disaster. The system is meant to assist the country, to move away from the approach of emergency response, to one of integrating disaster risk reduction into the developmental objectives of the country. In 2011, an invitation was sent to the University of Namibia for Namibia to be included in the most recent VFL data collection that was held, and given that Namibia is a country prone to floods, the invitation was therefore accepted.

\section{Literature review}

Flooding generally occurs in the Cuvelai Basin in northern Namibia, in areas around Oshakati, in the Oshana region. Water overflows the banks of the Zambezi River and this affects people living in low-lying areas. An assessment carried out by the DDRM reported that households are displaced annually during the rainy season and in most cases the displaced require food (maize meal) and non-food items (tents, blankets, soap, water purification tablets, emergency lighting, etc.). In the most extreme events, damage to property has included fields and houses flooded, clinics and schools closed down and roads and other infrastructure being washed away.

As previously indicated, such emergencies are recurring. It is therefore important to have a structure in place that coordinates initiatives pertaining to disaster risk reduction (Kandjinga 2011:1). In order to achieve this, the government needs to have a good disaster management system in place. Zoe et al. (2010:1) note that 'an effective disaster management system covers the following five aspects: (i) risk identification; (ii) emergency preparedness; (iii) institutional capacity building; (iv) risk mitigation; and (v) catastrophe risk financing'.

Namibia has the Office of the Prime Minister (OPM) which has the institutional capacity to manage natural hazards. The DDRM through the OPM usually carries out the risk assessment and coordinates the assessment of the risk and aid required in the vulnerable communities. In addition, the 
NAMVAC has been established to conduct vulnerability assessments for early warning purposes to identify vulnerable groups, the prevalence and degree of any given risk, and their causes using agreed indicators and assessment tools (Namibia National Disaster Risk Management Bill [NDRMB] 2011:3). Apart from these organisations, other organisations such as the Namibia Red Cross Society and the United Nations are also concerned with preparedness and flood monitoring, not leaving the scenario entirely up to the government.

A study carried out on southern African countries by Swain et al. (2011) found that socio-economic and political problems are disproportionately the consequences of hazards such as floods. Climate change and variability in weather patterns increases stresses on the socio-political fabric because it affects the governance of resources, and hence, is linked to the weakened mitigation and adaptation capacity of societies that are already facing economic challenges (rising food prices, etc.). Communities become more vulnerable when the resources they depend on are threatened (Gwimbi 2009:71). Furthermore, poor central leadership, weak institutions and polarised social identities can also make a society highly vulnerable to climate induced conflicts.

Taking all these factors into consideration, this study identifies Bulawayo (Matabeleland North) in Zimbabwe and the Zambezia Province in Mozambique as the regions most likely to experience climate induced conflicts in the near future. The reasons for identifying these two regions are: (1) increasing water scarcity in Bulawayo (Matabeleland North) and intensified flooding, sea-level rise, and coastal erosion in the Zambezia Province, (2) agricultural production in these two regions will become highly volatile, leading to severe food insecurity and (3) both regions are clearly suffering from poor political governance by unscrupulous elites, and the weak institutions and polarised social identities mentioned above.

Artan, Restrepo and Asante (2000) suggest that deployment of hydrologic models can help reduce human and economic losses in these regions by providing improved monitoring and forecast information to guide relief activities.

\section{Research methodology}

A quantitative survey was conducted using a questionnaire form with 20 questions. These were based on indicators of progress in 'local governance' in relation to disaster risk reduction:

Local governance is defined as comprising a set of institutions, mechanisms and processes, through which citizens and their groups can articulate their interests and needs, mediate their differences and exercise their rights and obligations at the local level. The building blocks of good local governance are many: citizen participation, partnerships among key actors at the local level, capacity of local actors across all sectors, multiple flows of information, institutions of accountability, and a propoor orientation. (United Nations Development Programme [UNDP] 2012:1)

Five themes were identified from the data collected in the VFL prohect. They are outlined below:
- Responsiveness: the ability to make decisions that take into account the needs, rights and entitlements of all citizen and stakeholders, including vulnerable and marginalised groups.

- Capability: individual and institutional capacities to organise and undertake actions, utilise opportunities and mobilise support.

- Accountability: means to hold public policy makers (duty bearers) to account to citizens (rights holders), including the ability to impartially measure progress towards objectives and targets.

- Transparency: facilitating easy public access to relevant information and processes relevant to building safety and resilience.

- Coherence: making different local people, organisations, sectors and disciplines work together to build safety and resilience.

Questions that dealt with the above five themes were aimed at the two key respondent groups, namely local government officials and community representatives. Respondents to the survey were asked to assess progress towards the various indicators by filling in the standardised questionnaires.

Vulnerable communities in the country were identified by developing a country profile identifying the main disaster risks at national and subnational levels. Information about hazards and vulnerability available from governmental departments and the media was used to identify at-risk communities. As recommended by the VFL project, 20 respondents from each community were approached - five local government officials and 15 community members. Interviews were conducted with the respondents after permission was granted by the local authorities at the beginning of the study. The officials were from local administrative authorities or were local representatives of central government departments and line-ministries and the community members were people living in the various atrisk communities selected, some in urban areas and others in the rural areas. The selected areas were from two North Central regions of Namibia, namely Oshana and Omusati. In the Oshana region, the areas that were selected were Evululuko, Okandjengedi, Oneshila and Oshoopala whilst in the Omusati region they were Okalongo, Anamulenge, Otamanzi and Outapi. Data collection was done through face-to-face interviews. Enumerators interviewed the respondents and recorded their answers on the questionnaire using a 5-point scale. The scores from all the questionnaires were then loaded into a simple, customised 'data entry tool' provided by the VFL and the mean scores were computed.

\section{Findings}

A total of 86 questionnaires was collected. Rural settlements contributed a total of $36 \%$ whilst the remaining $64 \%$ represents the urban settlements of the sample (Table 1).

TABLE 1: Participation based on rural and urban settlements.

\begin{tabular}{lcc}
\hline Settlements & Number of responses & Percentage \\
\hline Rural & 31 & 36.0 \\
Urban & 55 & 64.0 \\
\hline Total & $\mathbf{8 6}$ & $\mathbf{1 0 0 . 0}$ \\
\hline
\end{tabular}


There were significant differences in the rural and urban composition in the sample, although the total sample was predominantly rural (Figure 2). Locations such as Oneshila, Okandjengedi and Evululuko are urban locations.

\section{Gender of respondents}

The study had a contrasting representation of gender with respect to the locations selected. It was found that there was an overall equal representation of both male and female participants that took part in the study for the various areas visited (Figure 3).

\section{Age of respondents}

The floods in the north central regions of Namibia such as Oshana and Omusati affect all age groups, young and old. Generally, participants were between 26 and 60 years, with a mean of 4.01 and standard deviation of 0.985 (Figure 4). With regard to the selected areas, Anamulenge's population

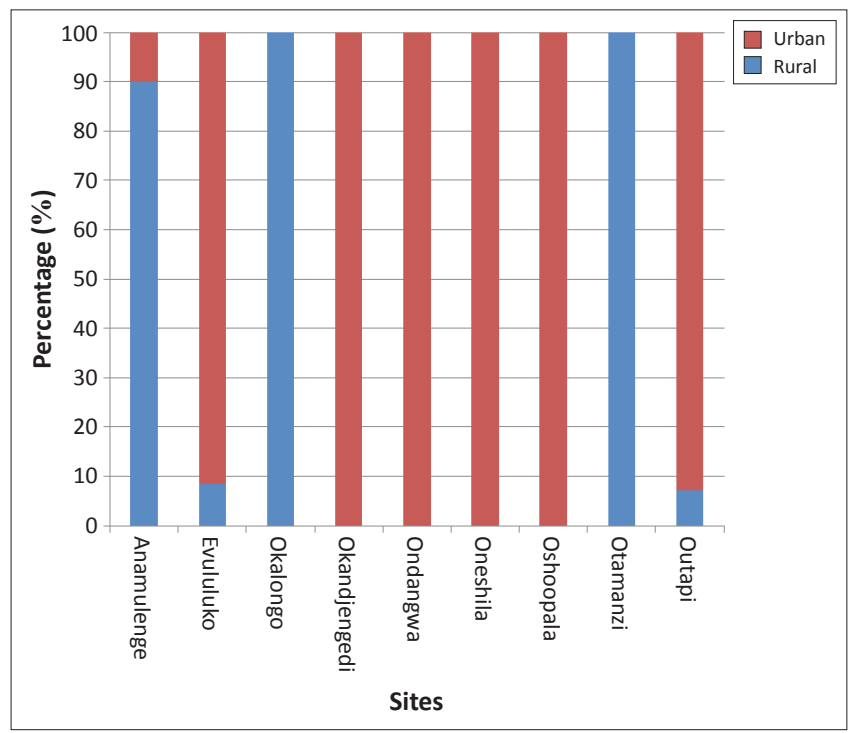

FIGURE 2: Locality of survey sites.

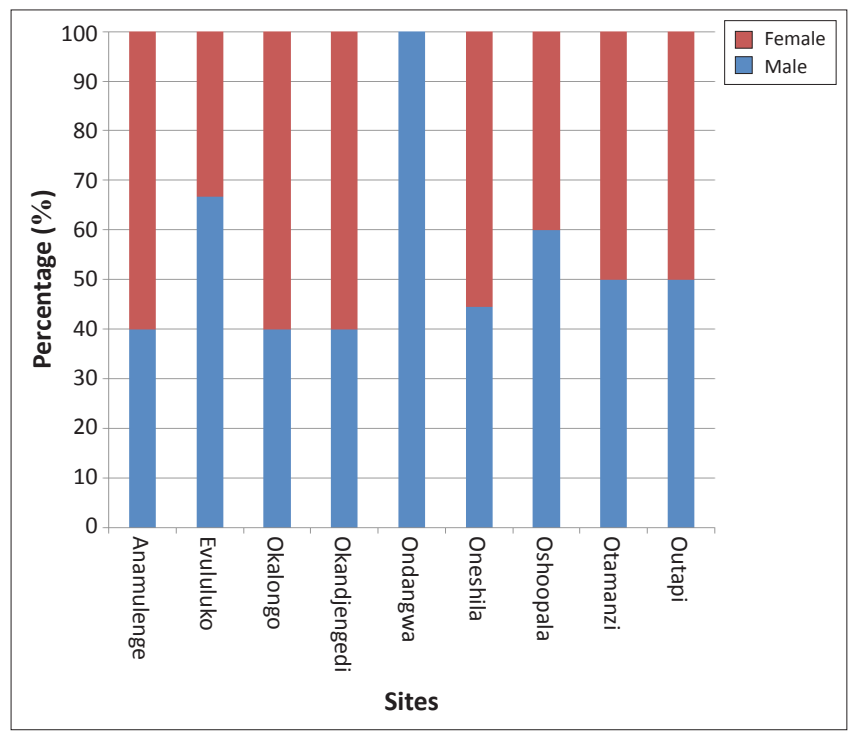

FIGURE 3: Gender by sites visited. is largely made up of senior citizens, whereas areas like Oneshila and Okandjengedi were represented by participants from the age group of 26-60 years.

\section{Informant groups}

Close to $90 \%$ of the respondents were from the community, whilst civil society and local government recorded $0.23 \%$ and $8 \%$ respectively. Local government respondents were mostly drawn from sites such as Outapi, Oshoopala, Okandjengedi and Evululuko (Figure 5).

\section{Changes by disaster losses using the descriptors}

This section will use the descriptors indicated in the report produced by the Global Network for Disaster Reduction of all the countries that participated in VFL 2011. The main variables for the analysis were 'threat and changes in disaster loss'. It is important to note the significance of losses to the victims of floods (Gwimbi 2009:72); loss of resources is the

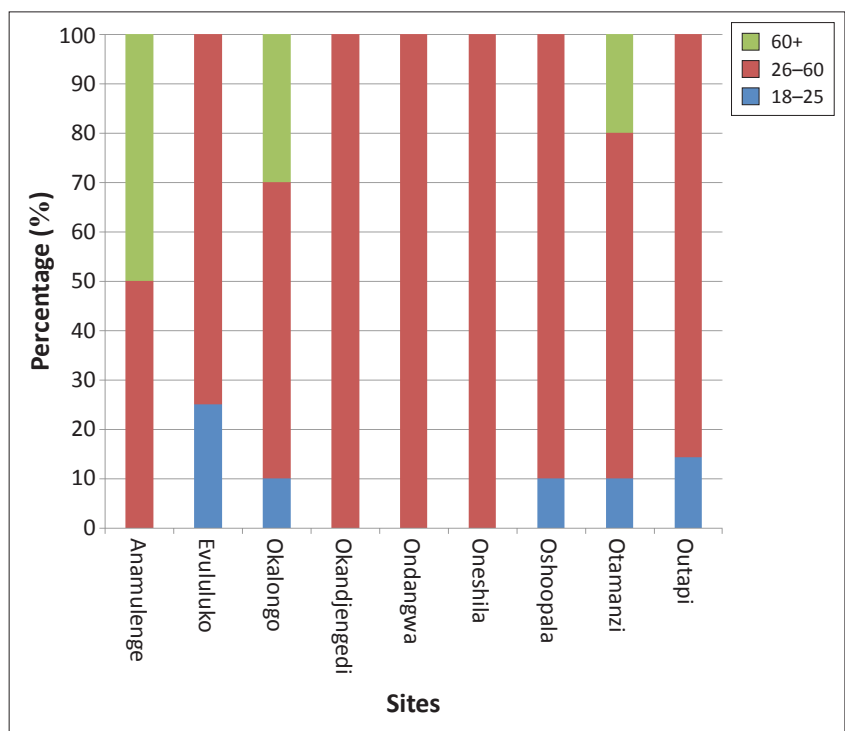

FIGURE 4: Age group as per survey site.

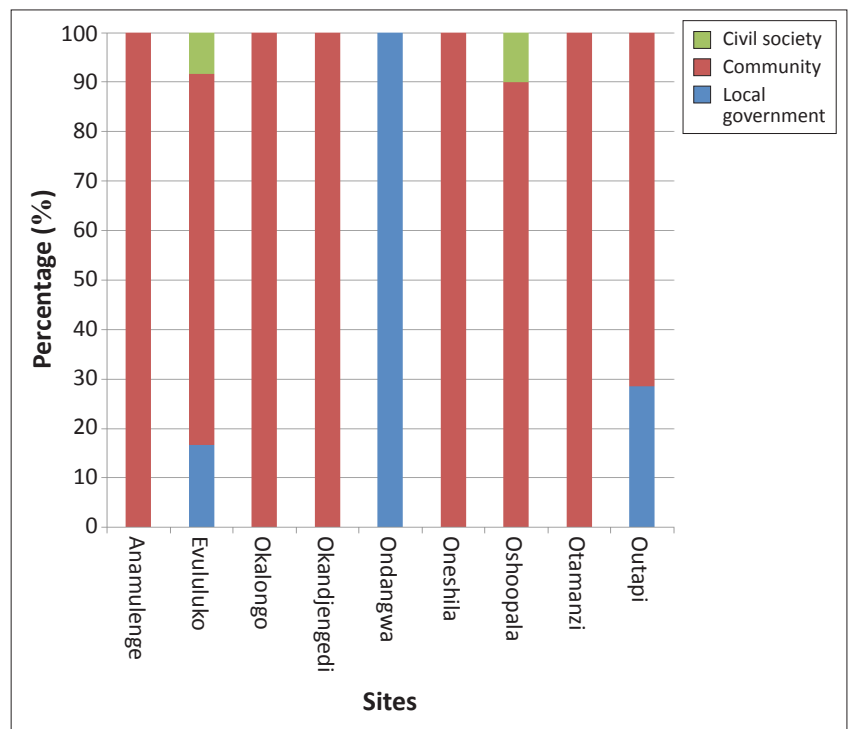

FIGURE 5: Informant groups as per sites visited. 
most important aspect with regard to floods. The question of how vulnerable communities are depends on the availability of alternative resources when disaster strikes. The availability of resources can increase flood victims' resilience to flood hazards, shocks and stresses.

\section{Threat}

Overall, respondents indicate that the threat of disasters seems to range between minimal and high, 2.3\% and $73.3 \%$ respectively (Table 2). Respondents in sites such as Evululuko and Oshoopala reported high threat of disaster in areas which are prone to disasters (Table 3). These were also the sites heavily affected by the latest flood disaster in Namibia, where close to $80 \%$ of the population in these areas was moved to higher ground.

In the sample, it seems that women perceived threat more accurately than men. A mean score of 4.09 against 3.91 was recorded (Table 4).

This threat seems to be informed by the informant groups in which the communities have a higher perception of threat (mean 4.08) compared to the local government and civil society (Table 5).

From Table 5, it appears that the community feels more threatened by disasters than local government and civil society. This does not come as a surprise because Namibia is a reactive country when it comes to disasters and therefore the community depends on government actions to decide when and how to respond to the situation on the ground. This confirms the argument earlier by Paton and Johnston (2001:270) that people think that the local government must take responsibility for managing their disaster.

\section{Changes in disaster loss over the last 5 years}

Overall, there was a general feeling that disaster losses over the 5 years had shown a decrease of $45 \%$ (Table 6).

Changes in disaster loss as per region reported an even distribution of losses over a 5 year period (Table 7). Table 10 shows the same trend in the sites visited. People in different locations perceive disaster losses differently. Evululuko, Okalongo, Oneshila, Otamanzi and Outapi reported a decrease in disaster losses over the last 5 years. It was only Okandjengedi and Oshoopala which recorded no difference in disaster losses over 5 years (Table 8).

With regard to changes in disaster losses in terms of age, the following emerges. In the age group of 26-60 years all respondents felt the same impact of changes in disaster losses (Table 9). This trend is confirmed by the mean score of -25 (Table 10).

Both genders experience changes in disaster losses, but as indicated by Table 12, it seems that women have a more deleterious experience of changes in disaster loss, with mean scores from -0.58 to -0.21 respectively (Tables 11 and 12 ).
TABLE 2: Perception of threat of disasters.

\begin{tabular}{lcc}
\hline Risk indicator & Number of responses & Percentage \\
\hline Minimal & 2 & 2.3 \\
Low & 6 & 7.0 \\
Medium & 15 & 17.4 \\
High & 63 & 73.3 \\
\hline Total & $\mathbf{8 6}$ & $\mathbf{1 0 0}$ \\
\hline
\end{tabular}

TABLE 3: Disaster threat by sites.

\begin{tabular}{lcccccc}
\hline Sites & Minimal & Low & Medium & High & Very high & Total \\
\hline Anamulenge & 0 & 1 & 1 & 4 & 4 & 10 \\
Evululuko & 1 & 0 & 0 & 3 & 7 & 11 \\
Okalongo & 0 & 2 & 0 & 5 & 3 & 10 \\
Okandjengedi & 1 & 1 & 5 & 2 & 2 & 11 \\
Oneshila & 0 & 1 & 0 & 4 & 4 & 9 \\
Oshoopala & 0 & 0 & 1 & 5 & 5 & 11 \\
Otamanzi & 0 & 1 & 3 & 2 & 4 & 10 \\
Outapi & 0 & 0 & 5 & 5 & 4 & 14 \\
\hline Total & $\mathbf{2}$ & $\mathbf{6}$ & $\mathbf{1 5}$ & $\mathbf{3 0}$ & $\mathbf{3 3}$ & $\mathbf{8 6}$ \\
\hline
\end{tabular}

TABLE 4: Perceived threat by gender (mean scores).

\begin{tabular}{lccc}
\hline Gender & Mean & Population & Standard deviation \\
\hline Male & 3.91 & 43 & 1.130 \\
Female & 4.09 & 43 & 0.921 \\
\hline Total & $\mathbf{4 . 0 0}$ & $\mathbf{8 6}$ & $\mathbf{1 . 0 2 9}$ \\
\hline
\end{tabular}

TABLE 5: Perceived threat by informant groups (mean scores).

\begin{tabular}{lccc}
\hline Informant Group & Mean & Population & Standard deviation \\
\hline Local government & 3.43 & 7 & 0.787 \\
Community & 4.08 & 77 & 0.984 \\
Civil society & 3.00 & 2 & 2.828 \\
\hline Total & 4.00 & 86 & 1.029 \\
\hline
\end{tabular}

TABLE 6: Changes in disaster losses over the last 5 years.

\begin{tabular}{lcc}
\hline Indicator & Number of responses & Percentage \\
\hline Slight decrease & 17 & 19.8 \\
Substantial decrease in losses & 22 & 25.6 \\
No change & 27 & 31.4 \\
Substantial increase in loses & 18 & 20.9 \\
Slight increase & 2 & 2.3 \\
\hline Total & $\mathbf{8 6}$ & $\mathbf{1 0 0 . 0}$ \\
\hline
\end{tabular}

TABLE 7: Changes in disaster loss per region.

\begin{tabular}{lcccccc}
\hline Region & $\begin{array}{c}\text { Slight } \\
\text { decrease }\end{array}$ & $\begin{array}{c}\text { Substantial } \\
\text { decrease }\end{array}$ & $\begin{array}{c}\text { No } \\
\text { change }\end{array}$ & $\begin{array}{c}\text { Substantial } \\
\text { increase in } \\
\text { losses }\end{array}$ & $\begin{array}{c}\text { Slight } \\
\text { increase }\end{array}$ & Total \\
\hline Omusati & 8 & 12 & 15 & 7 & 2 & 44 \\
Oshana & 9 & 10 & 12 & 11 & 0 & 42 \\
\hline Total & $\mathbf{1 7}$ & $\mathbf{2 2}$ & $\mathbf{2 7}$ & $\mathbf{1 8}$ & $\mathbf{2}$ & $\mathbf{8 6}$ \\
\hline
\end{tabular}

TABLE 8: Changes in disaster loss per site.

\begin{tabular}{lcccccc}
\hline Locality & $\begin{array}{c}\text { Slight } \\
\text { decrease }\end{array}$ & $\begin{array}{c}\text { Substantial } \\
\text { decrease }\end{array}$ & $\begin{array}{c}\text { No } \\
\text { change }\end{array}$ & $\begin{array}{c}\text { Substantial } \\
\text { increase in } \\
\text { losses }\end{array}$ & $\begin{array}{c}\text { Slight } \\
\text { increase }\end{array}$ & Total \\
\hline Anamulenge & 4 & 1 & 3 & 2 & 0 & 10 \\
Evululuko & 4 & 2 & 3 & 2 & 0 & 11 \\
Okalongo & 1 & 5 & 4 & 0 & 0 & 10 \\
Okandjengedi & 1 & 2 & 5 & 3 & 0 & 11 \\
Oneshila & 3 & 2 & 2 & 2 & 0 & 9 \\
Oshoopala & 1 & 3 & 3 & 4 & 0 & 11 \\
Otamanzi & 2 & 2 & 3 & 3 & 0 & 10 \\
Outapi & 1 & 5 & 4 & 2 & 2 & 14 \\
\hline Total & $\mathbf{1 7}$ & $\mathbf{2 2}$ & $\mathbf{2 7}$ & $\mathbf{1 8}$ & $\mathbf{2}$ & $\mathbf{8 6}$ \\
\hline
\end{tabular}


TABLE 9: Changes in disaster loss per age group.

\begin{tabular}{lcccccc}
\hline Age & $\begin{array}{c}\text { Slight } \\
\text { decrease }\end{array}$ & $\begin{array}{c}\text { Substantial } \\
\text { decrease }\end{array}$ & $\begin{array}{c}\text { No } \\
\text { change }\end{array}$ & $\begin{array}{c}\text { Substantial } \\
\text { increase in } \\
\text { losses }\end{array}$ & $\begin{array}{c}\text { Slight } \\
\text { increase }\end{array}$ & Total \\
\hline $18-25$ & 3 & 2 & 3 & 0 & 0 & 8 \\
$26-60$ & 10 & 19 & 19 & 18 & 2 & 68 \\
$60>$ & 4 & 1 & 5 & 0 & 0 & 10 \\
\hline Total & $\mathbf{1 7}$ & $\mathbf{2 2}$ & $\mathbf{2 7}$ & $\mathbf{1 8}$ & $\mathbf{2}$ & $\mathbf{8 6}$ \\
\hline
\end{tabular}

TABLE 10: Changes in disaster loss (mean score of age).

\begin{tabular}{lccc}
\hline Age & Mean & $\boldsymbol{n}$ & Standard deviation \\
\hline $18-25$ & -1.00 & 8 & 0.926 \\
$26-60$ & -0.25 & 68 & 1.098 \\
$60>$ & -0.90 & 10 & 0.994 \\
\hline Total & -0.40 & 86 & 1.098 \\
\hline
\end{tabular}

TABLE 11: Changes in disaster loss by gender.

\begin{tabular}{lcccccc}
\hline Gender & $\begin{array}{c}\text { Slight } \\
\text { decrease }\end{array}$ & $\begin{array}{c}\text { Substantial } \\
\text { decrease }\end{array}$ & $\begin{array}{c}\text { No } \\
\text { change }\end{array}$ & $\begin{array}{c}\text { Substantial } \\
\text { increase In } \\
\text { losses }\end{array}$ & $\begin{array}{c}\text { Slight } \\
\text { increase }\end{array}$ & Total \\
\hline Male & 6 & 11 & 13 & 12 & 1 & 43 \\
Female & 11 & 11 & 14 & 6 & 1 & 43 \\
\hline Total & $\mathbf{1 7}$ & $\mathbf{2 2}$ & $\mathbf{2 7}$ & $\mathbf{1 8}$ & $\mathbf{2}$ & $\mathbf{8 6}$ \\
\hline
\end{tabular}

TABLE 12: Changes in disaster loss by gender (mean scores).

\begin{tabular}{lccc}
\hline Gender & Mean & $\boldsymbol{n}$ & Standard deviation \\
\hline Male & -0.21 & 43 & 1.081 \\
Female & -0.58 & 43 & 1.096 \\
\hline Total & $-\mathbf{0 . 4 0}$ & $\mathbf{8 6}$ & $\mathbf{1 . 0 9 8}$ \\
\hline
\end{tabular}

With regard to disaster losses by informant groups, community members are the ones feeling it the most. They have a more negative view that can mostly be related to the slowness of the authorities to deal with the issues at hand for community members (Tables 13 and 14).

\section{Local governance issues}

Valid cases for all indicators are fairly close, although local government appears to be performing better on participation, children and youth, and least well on information management and providing financial resources (Table 15).

\section{Relationship of local governance and descriptors}

If the two study sites are ranked according to the overall mean score with regard to local governance indicators, the Oshana region is doing particularly well as opposed to Omusati, with a score of 3.06 compared to 2.7 (Table 16). This is due to the fact that Oshana region is an urban area as compared to Omusati. Oshana local governance is more active in terms of responding to the needs of disaster victims than the traditional authority in the Omusati region.

\section{Discussion}

The aim of this study was to investigate the views of communities, government and civil society on their views of floods as a disaster in Namibia. The identified regions which are affected by floods were Omusati and Oshana. The aim is to assist in building the resilience of vulnerable people and communities at risk to disasters by strengthening
TABLE 13: Changes in disaster loss per informant groups.

\begin{tabular}{lcccccc}
\hline Groups & $\begin{array}{c}\text { Slight } \\
\text { decrease }\end{array}$ & $\begin{array}{c}\text { Substantial } \\
\text { decrease }\end{array}$ & $\begin{array}{c}\text { No } \\
\text { change }\end{array}$ & $\begin{array}{c}\text { Substantial } \\
\text { increase in } \\
\text { losses }\end{array}$ & $\begin{array}{c}\text { Slight } \\
\text { increase }\end{array}$ & Total \\
\hline Local & 1 & 1 & 2 & 3 & 0 & 7 \\
Community & 16 & 21 & 23 & 15 & 2 & 77 \\
Civil Society & 0 & 0 & 2 & 0 & 0 & 2 \\
\hline Total & $\mathbf{1 7}$ & $\mathbf{2 2}$ & $\mathbf{2 7}$ & $\mathbf{1 8}$ & $\mathbf{2}$ & $\mathbf{8 6}$
\end{tabular}

TABLE 14: Changes in disaster loss per informant groups (mean scores).

\begin{tabular}{lccc} 
Informant Group & Mean & $\boldsymbol{n}$ & Standard deviation \\
\hline Local government & 0.00 & 7 & 1.155 \\
Community & -0.44 & 77 & 1.106 \\
Civil Society & 0.00 & 2 & 0.000 \\
\hline Total & $-\mathbf{0 . 4 0}$ & $\mathbf{8 6}$ & $\mathbf{1 . 0 9 8}$ \\
\hline
\end{tabular}

TABLE 15: Views on local governance.

\begin{tabular}{lcc}
\hline Local Governance indicators & Responses & Missing cases \\
\hline Participation & 86 & 0 \\
Gender & 83 & 3 \\
Children and youth & 85 & 1 \\
Volunteers & 79 & 7 \\
Policies & 81 & 5 \\
Indigenous capacities & 83 & 3 \\
Planning & 76 & 10 \\
Financial resources & 67 & 19 \\
Decentralisation & 82 & 4 \\
Expertise & 83 & 3 \\
Training & 84 & 2 \\
Baselines & 74 & 12 \\
Monitoring & 84 & 2 \\
Participatory monitoring & 85 & 1 \\
Complaints procedures & 82 & 4 \\
Information gathering & 82 & 4 \\
Information management & 74 & 12 \\
Information dissemination & 82 & 4 \\
Governmental coordination & 80 & 6 \\
Partnership & 78 & 8 \\
\hline & & \\
\hline & & \\
\hline
\end{tabular}

public accountability for effective HFA implementation. The other goals are to strengthen collaboration between local, national, regional and international levels, and to increase dialogue and interaction between local authorities, civil society and community stakeholders to monitor progress, share information, formulate policy positions, develop partnerships and coalitions and to contribute towards multistakeholders' efforts to implement the HFA on the ground.

The results from communities, government and civil society affected by floods indicate that the community seems to be threatened more by floods as opposed to the local government and civil society. Government does not seem to have the expertise and resources to train individuals on how to protect themselves from floods if they cannot come up with a plan for building infrastructure that will prevent water from reaching the communities where individuals are residing. The results point to a situation in which the majority of respondents feel that losses in the regions show no change. Residents of Evululuko are more threatened by disasters as they feel that the risk is very high compared to those in Okandjendedi who feel that disaster threats are at a minimum. 
TABLE 16: Governance indicators region and mean scores.

\begin{tabular}{|c|c|c|c|c|c|c|c|c|c|}
\hline \multirow[t]{2}{*}{ Indicators } & \multicolumn{3}{|c|}{ Omusati } & \multicolumn{3}{|c|}{ Oshana } & \multicolumn{3}{|c|}{ Total } \\
\hline & Mean & Standard deviation & $n$ & Mean & Standard deviation & $n$ & Mean & Standard deviation & $n$ \\
\hline Participation & 2.61 & 1.558 & 44 & 2.79 & 1.747 & 42 & 2.70 & 1.645 & 86 \\
\hline Gender & 3.28 & 1.453 & 43 & 3.38 & 1.675 & 40 & 3.33 & 1.555 & 83 \\
\hline Children and youth & 3.09 & 1.507 & 44 & 2.85 & 1.558 & 41 & 2.98 & 1.527 & 85 \\
\hline Volunteers & 2.35 & 1.442 & 40 & 3.08 & 1.645 & 39 & 2.71 & 1.578 & 79 \\
\hline Policies & 3.10 & 1.465 & 39 & 3.02 & 1.352 & 42 & 3.06 & 1.400 & 81 \\
\hline Indigenous capacities & 2.55 & 1.214 & 42 & 2.39 & 1.394 & 41 & 2.47 & 1.300 & 83 \\
\hline Planning & 2.51 & 1.412 & 39 & 3.30 & 1.412 & 37 & 2.89 & 1.457 & 76 \\
\hline Financial resources & 2.21 & 1.495 & 33 & 2.91 & 1.545 & 34 & 2.57 & 1.549 & 67 \\
\hline Decentralisation & 3.05 & 1.413 & 43 & 3.23 & 1.512 & 39 & 3.13 & 1.455 & 82 \\
\hline Expertise & 2.40 & 1.326 & 42 & 2.27 & 1.361 & 41 & 2.34 & 1.337 & 83 \\
\hline Training & 2.17 & 1.480 & 42 & 2.21 & 1.523 & 42 & 2.19 & 1.493 & 84 \\
\hline Baselines & 2.65 & 1.252 & 37 & 3.08 & 1.441 & 37 & 2.86 & 1.358 & 74 \\
\hline Monitoring & 3.40 & 1.345 & 42 & 3.31 & 1.569 & 42 & 3.36 & 1.453 & 84 \\
\hline Participatory monitoring & 3.02 & 1.504 & 43 & 3.00 & 1.431 & 42 & 3.01 & 1.460 & 85 \\
\hline Complaints procedures & 2.70 & 1.582 & 43 & 3.10 & 1.603 & 39 & 2.89 & 1.595 & 82 \\
\hline Information gathering & 2.84 & 1.557 & 43 & 3.49 & 1.412 & 39 & 3.15 & 1.516 & 82 \\
\hline Information & 2.74 & 1.465 & 38 & 2.89 & 1.450 & 36 & 2.81 & 1.449 & 74 \\
\hline Management & 3.12 & 1.626 & 42 & 3.53 & 1.519 & 40 & 3.32 & 1.578 & 82 \\
\hline Information dissemination & 2.88 & 1.435 & 41 & 4.03 & 1.267 & 39 & 3.44 & 1.466 & 80 \\
\hline Governmental Coordination & - & - & - & - & - & - & - & - & - \\
\hline Partnership & 3.15 & 1.621 & 41 & 3.76 & 1.362 & 37 & 3.44 & 1.525 & 78 \\
\hline LGMEAN2 & 2.787422 & .7028115 & 44 & 3.069371 & .7157883 & 42 & 2.925118 & .7191031 & 86 \\
\hline
\end{tabular}

Study achieved its objectives by strengthening collaboration between local, national, regional and international levels. Furthermore, it created a platform for dialogue between local authorities, civil society and community stakeholders to share information, develop partnerships and coalitions and contribute towards multi-stakeholders' efforts to implement the HFA on the ground.

In future, resilience strategies in the context of the capacity building of marginalised rural communities in different aspects of resilience will be emphasised. Marjanovic and Nimpuno (2003) stress that:

... living with risk is the order of the day, and we must learn to reduce these risks through appropriate measures focused on planning, forecasting and mitigation. We need to build a world of resilient people, communities and nations. (p. 197)

The sentiments shared by the respondents that took part in this study stipulate that the infrastructure must be put in place to make schools accessible to learners during the rainy seasons and to ensure that people are not at risk of drowning as they carry out their daily activities. It has been noted that Government provide resources such as sand to create embankments to prevent water from entering and destroying properties, but with limited success. Although the role of government is decision making and implementation, it has been noted that people in the community are not aware of the people who are meant to serve them. The process of communication in terms of disaster reporting by community members to local government is compromised, as the channels of communication are often not known by the masses. 'They come with people from other areas, and tell us to call them if we have problems relating to a disaster' (female member of a household, 30-40-year age group).
Thomalla et al. (2006) note that disaster risk reduction, climate change adaptation, environmental management and poverty reduction are all strategies aimed at reducing socio-economic vulnerability to natural hazards. However, despite the significant efforts of communities, the vulnerability of many individuals and communities to natural hazards continues to increase. In particular, hydro-meteorological hazards affect an increasing number of people and cause increasingly large economic losses. Although Africa is the continent least responsible for greenhouse gas emissions, it is almost universally seen as the continent most at risk of climateinduced conflicts (Brown \& Crawford 2009). Arising from the realisation that communities in Africa have been largely working in isolation and have enjoyed only limited success in reducing vulnerability, there is a clear need to strengthen collaboration significantly and to facilitate learning and information exchange between them.

\section{Conclusion}

At this stage, it is known by government, community members and other stakeholders in society that natural hazards, especially floods, are a serious threat to the social, economic and political aspects of the country and can hinder development and growth of a nation. It is thus essential that disaster risk reduction is carried out by all individuals in society at various levels. With the Disaster Risk Management Bill and Policy of Namibia, it is essential that activities and objectives of this policy be integrated in all developmental activities of every line ministry, non-governmental organisations of all nature, humanitarian aid in Namibia and community based organisations. Furthermore, information and decision making related to disaster risk reduction is 
openly shared by all stakeholders and the society at large and not only the Directorate of Disaster Risk Management which is only based in Windhoek. Line ministries at regions should work closely with the village headmen and community leaders such as the church elders as they are persons that are closer to people at grassroots level and can communicate easily and understandably with them, for example, during church services.

This study has limitations because it covered only two regions in Namibia, in the North Central part of the country. In reality, floods also affect the north-eastern region of Namibia with greater impact at times than in the regions included in this study. The study might also have restricted the respondents because the questionnaire only had indicators instead of open-ended questions. Furthermore, the method of data collection restricted the data for further analysis, as it was collected in categories and no inferential analysis could be done, simply descriptive statistics.

\section{As stated by O'Brien et al. (2010):}

Building resilience although there is a human-environment interaction that might cause a disaster, it is the space where interventions can refocus on preparedness, and how to build on local knowledge, informed by predictions of possible climate changes, a shift in behaviour of how we respond resulted in preparedness created by resilience and coping capacity. (p. 504)

\section{Recommendations}

For future research, the researchers suggest a comparative study of the North Central regions with those in the northeastern regions. The study should be structured in a way that allows more views and opinions of respondents to be collected. Further recommendations are:

- Government and all stakeholders should make a thorough assessment of all flood prone areas and integrate disaster risk reduction in their programmes instead of using the approach of emergency response. In other words, the government and stakeholders should move from a reactive approach and adopt a strictly proactive approach in response to the risk of floods in the regions studied and in other affected areas in the country.

- Communities in the affected regions need to be sensitised about flood risks well in time so that they will be prepared when disasters strike. Capacity building programmes need to be put in place to facilitate community involvement and collaboration.

\section{Acknowledgements}

The authors wish to acknowledge all the community members as well as local government respondents for their valuable contribution in completing the VFL study on which this article was compiled. The authors would like to acknowledge the funding received from USAID under grant no: AIDOFDA-G-11-00077 for the field research.

\section{Competing interests}

The authors declare that they have no financial or personal relationship(s) that may have inappropriately influenced them in writing this article.

\section{Authors' contributions}

G.v.R. (University of Namibia) conceptualised the article. E.A. (University of Namibia) and G.v.R. compiled the article. L.S. (North-West University) carried out data analysis and intepretation of results. N.S. (University of Namibia) contributed to discussion, conclusion and recommendations.

\section{References}

Ahrens, J. \& Rudolph, P., 2006, 'The importance of governance in risk reduction and disaster management', Journal of Contingencies and Crisis Management 14, 207-220. http://dx.doi.org/10.1111/j.1468-5973.2006.00497.x

Artan, G.A., Restrepo, M. \& Asante, K., 2000, 'A flood early warning system for Southern Africa', Pecora 15/Land Satellite Information IV/ISPRS Commission I/FIEOS 2002 Conference Proceedings.

Brown, O. \& Crawford, A., 2009, Climate change and security in Africa, International Institute for Sustainable Development, Manitoba.

Fara, K., 2001, 'How natural are "natural disasters"? Vulnerability to drought of communal farmers in southern Namibia', Risk Management: An International Journal 3(3), $47-63$.

Gwimbi, P., 2009, 'Linking rural community livelihoods to resilience building in flood risk reduction in Zimbabwe', Journal of Disaster Risk Studies 2(1), 81-92.

Kandjinga, J.L., 2011, 'The role of land use in reducing Oneshila informal settlement's vulnerability to floods', Final IECN research report, 11 November, 2010, Polytechnic of Namibia, Windhoek.

Kobetsu, L., 2010, 'Cabinet approves draft Disaster Risk Management Bill', The Namibia Economist, 15 October, p. 5.

Kreimer, A. \& Arnold, M. (eds.), 2000, Managing disaster risks in emerging economies, The International Bank for Reconstruction and Development, New York.

Maguire, B. \& Hagan, P., 2007, 'Disasters and communities: Understanding social resilience', The Australian Journal of Emergency Management 22(2), 16-20.

Marjanovic, P. \& Nimpuno, K., 2003, 'Living with risk: Toward effective disaster management in Africa', in A. Kreimer, M. Arnold \& A. Carlin (eds.), Building safer cities: The future of disaster risk, pp. 197-240, World Bank, Washington DC.

Namibia National Disaster Risk Management Bill (NDRMB), 2001, Government of the Republic of Namibia, Windhoek, Namibia.

O’Brien, G., O'Keefe, P., Gadema, Z. \& Swords, J., 2010, 'Approaching disaster management through social learning', Disaster Prevention and Management 19(4), 498-508. http://dx.doi.org/10.1108/09653561011070402

Paton, D. \& Johnston, D., 2001, 'Disasters and communities: Vulnerability, resilience and preparedness', Disaster Prevention and Management 10(4), 270-277.

Pelling, M. \& Wisner, B. (eds.), 2009. Disaster risk reduction - Cases from urban Africa, Earthscan, London.

Relief Web, 2009, Report on the flooding in Namibia and Angola, viewed 15 March 2011, from http://reliefweb.int/node/301823

Swain, A., Swain, R.B., Themnér, A. \& Krampe, F., 2011, 'Climate change and the risk of violent conflicts in Southern Africa: Satellite image showing the Zambezi river's annual flood near the small city of Kasane in the Zambezi's upper reaches', Global Crisis Solutions, Pretoria.

Thomalla, F., Downing, T., Spanger-Siegfried, E., Han, G. \& Rockström, J., 2006, 'Reducing hazard vulnerability: Towards a common approach between disaster risk reduction and climate adaptation', Disasters 30(1), 39-48. http://dx.doi.org/10.1111/j.14679523.2006.00305.x, PMid:16512860

Twigg, J., 2007, Characteristics of a disaster risk-resilient community: A guidance note Bangladesh, viewed 05 June 2012, from http://www.benfieldhrc.org/disaster studies/projects/communitydrrindicators/community_drr_indicators_index.htm

United Nations Development Programme (UNDP), 2012, Local governance, human rights based approach and gender mainstreaming in the context of Europe and the CIS,
viewed 05 June 2012, from http://hrba.undp.sk/index.php/introduction/localhuman-rights-based-approach-and-gender-mainstreaming-in-the-context-ofeurope-and-the-cis/182-local-governance- webpage governance

United Nations, 2005, Hyogo Framework for Action, viewed 29 June 2012, from http:// www.unisdr.org/we/coordinate/hfa

Van Niekerk, D., 2006, 'Disaster risk management in South Africa: The function and the activity - Towards an integrated approach', Politeia 25(2), 95-115.

Zoe, T., Arish, D., Ting, A. \& Dean, C., 2010, Disaster risk reduction, viewed 18 September 2012, from https://openknowledge.worldbank.org/handle/10986/10124 License 